\title{
Sex Difference in X-Linked Glucose 6-Phosphate Dehydrogenase Activity of Mouse Embryos
}

\author{
Takashi Miyano, Kenji Naohara, Seishiro Kato, \\ and Sunao KANDA \\ Laboratory of Animal Reproduction, Faculty of Agriculture, \\ Kobe University, Kobe 657, Japan
}

(Accepted for publication June 13, 1990)

\begin{abstract}
Summary. The activity of an X-linked enzyme, glucose 6-phosphate dehydrogenase (G6PD), was measured in preimplantation mouse embryos by a simple in situ colorimetric assay (Williams, 1986). Morulae and blastocysts were sufficiently stained by brilliant cresyl blue to determine the enzymatic activity, whereas 1- to 8-cell embryos were not. The distribution of the enzymatic activities at the blastocyst stage were bimodal, although the activity was lower than that obtained at the morula stage. Morulae or blastocysts grouped according to the G6PD activity were transferred separately to pseudopregnant females. Sex ratio (number of males/total number of pups) of newborns derived from morulae with high (putative female) and low (putative male) activity were 0.407 and 0.593 , respectively, and those derived from blastocysts with high and low activity were 0.405 and 0.649. KEY WORDS: G6PD, X-LINKED ENZYME, SEX RATIO, BLASTOCYST, EMBRYO TRANSFER.
\end{abstract}

Jpn J Anim Reprod 36, 209-212, 1990

In female somatic cells of mammals, one of the X-chromosomes is inactive, while in germ cells both $\mathrm{X}$-chromosomes are active during a certain period (Lyon, 1961, 1974). In the mouse, both $\mathrm{X}$-chromosomes are functional in oocytes during the growth phase (Epstein, 1969, 1972). After fertilization, activation of both maternal and paternal X-chromosomes in female embryos occurs from the 2-cell stage (Schultz, 1986) and lasts up to the blastocyst stage when one of the X-chromosomes becomes inactive (Epstein, 1972; Adler et al., 1977; Kratzer and Gartler, 1978). It has been reported that $\mathrm{X}$-linked enzymes, such as hypoxanthineguanine phosphoribosyl transferase (HGPRT) and $\alpha$-galactosidase ( $\alpha$-Gal), exhibit twice as much activity in female embryos as compared to male embryos during this period (Epstein et al., 1978; Adler et al., 1977).
Recently, the measurement of X-linked enzyme activity has been applied to the sexing of preimplantation embryos. Williams (1986) measured the activity of an X-linked enzyme, glucose 6-phosphate dehydrogenase (G6PD), in Day 4 mouse embryos using a simple colorimetric assay, and demonstrated that $64 \%$ of the embryos were correctly sexed prior to transfer. In this study, we determined an appropriate developmental stage of mouse embryo for the G6PD colorimetric assay, and examined the relationship between the G6PD activity of embryos and the sex ratio of newborns derived from embryos grouped according to the activity.

\section{Materials and Methods}

\section{Experiment 1}

Female ICR mice were injected intraperitoneally with 5 IU PMSG (Teikoku Zoki, 
Japan) followed $48 \mathrm{hr}$ later by 5 IU hCG (Sankyo Zoki, Japan). Treated mice were mated with ICR males, and 1-, 2- 4- and 8-cell embryos, morulae and blastocysts were collected at 16, 44, 60, 68, 78 and $92 \mathrm{hr}$ after hCG injection, respectively. Embryos were washed in $0.1 \mathrm{ml}$ of M2 medium (Quinn et al., 1982) supplemented with $0.05 \mathrm{mg}$ brilliant cresyl blue (BCB, Sigma, USA) $/ \mathrm{ml}$, and stained in the medium for $20 \mathrm{~min}$ at $37^{\circ} \mathrm{C}$. They were transferred into $0.1 \mathrm{ml}$ of the reaction mixture: M2 medium supplemented with $0.5 \mathrm{mM} \beta$-nicotine adenine dinucleotide phosphate (Olyental, Japan) and $0.5 \mathrm{mM}$ Na-glucose 6-phosphate (Olyental, Japan). The stained embryos in the medium were examined every $6 \mathrm{~min}$, and the number of embryos displaying decolored BCB were recorded. Activity of G6PD was represented by the time required for decolorization of $\mathrm{BCB}$.

\section{Experiment 2}

Female ddY mice were mated with mature vasectomized male ddY mice, and females with a vaginal plug on the next morning (day 1) were used for recipients. Morulae were recovered from female ICR mice as described above. After measurement of G6PD activity, 167 embryos with high activity (putative females) and 166 with low activity (putative males) were transferred separately into the uteri of 24 recipients on day 3 of pseudopregnancy. Control morulae $(n=92)$ cultivated for 2 to $3 \mathrm{hr}$ in M2 medium were transferred to 7 females in the same manner.

Blastocysts were also divided into two groups after measurement of G6PD activity, and 133 putative female embryos and 134 putative male embryos were transferred separately into the uteri of 34 pseudopregnant mice on day 4 of pseudopregnancy. Control blastocysts $(n=79)$ were transferred to 5 females. The sex of the resulting newborns was examined at birth. The statistical analysis was performed by $\chi^{2}$-test.

\section{Results}

G6PD activity in mouse embryos

Morulae and blastocysts were stained with BCB, while 1-, 2-, 4- and 8-cell embryos were not, suggesting that this colorimetric assay can be applied to the measurement of G6PD activity only at the morula and blastocyst stages. After transfer of stained embryos into the reaction mixture, $\mathrm{BCB}$ was gradually decolored and the embryos eventually returned to a pre-stained state. Figure 1 shows the distributions of G6PD activity of each embryo at the morula and blastocyst stages. The average activity of 71 morulae was $40.9 \pm 15.3 \mathrm{~min}$, while the activity of 52 blastocysts was $51.0 \pm 18.7 \mathrm{~min}$. A bimodal distribution was seen at the blastocyst stage, while it was not clear at the morula stage. The average activities for the two modes of the bimodal distribution at the blastocyst stage were $33.5 \pm 8.8 \mathrm{~min}$ ( 28 blastocysts with high G6PD activity) and 66.0 $19.5 \mathrm{~min}$ (24 with low activity). There was a two-fold difference between the modes (1.97:1).

Relationship between G6PD activity and newborn sex ratio

Two groups of morulae, with high- and low-G6PD activities, were transferred to 12 and 12 recipients, subsequently, 8 and 8

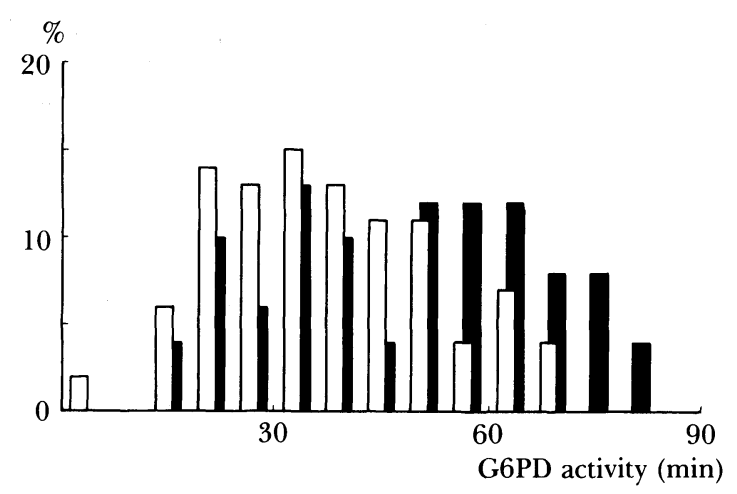

Fig. 1. Distribution of glucose 6-phosphate dehydrogenase (G6PD) activities of mouse morulae and blastocysts.

$\square$ : morula $(\mathrm{n}=71)$, $\mathbf{a}$ : blastocyst $(\mathrm{n}=52)$ 
Table 1. Sex ratio of newborn mice derived from embryos with high- and low-glucose 6-phosphate dehydrogenase (G6PD) activity

\begin{tabular}{clccccc}
\hline \hline $\begin{array}{c}\text { Developmental } \\
\text { stage of } \\
\text { embryos }\end{array}$ & $\begin{array}{c}\text { G6PD } \\
\text { activity }\end{array}$ & $\begin{array}{c}\text { No. of } \\
\text { embryos } \\
\text { transferred }\end{array}$ & $\begin{array}{c}\text { No. of } \\
\text { newborn } \\
\text { mice }\end{array}$ & $\begin{array}{c}\text { No. of } \\
\text { males }\end{array}$ & $\begin{array}{c}\text { No. of } \\
\text { females }\end{array}$ & $\begin{array}{c}\text { Sex } \\
\text { ratio }^{\text {1) }}\end{array}$ \\
\hline Morula & High & 167 & 59 & 24 & 35 & 0.407 \\
& Low & 166 & 54 & 32 & 22 & 0.593 \\
& Control & 92 & 34 & 18 & 16 & 0.529 \\
\hline \multirow{2}{*}{ Blastocyst } & High & 133 & 42 & 17 & 25 & $0.405^{\text {a }}$ \\
& Low & 134 & 74 & 48 & 26 & $0.649^{\text {b }}$ \\
& Control & 79 & 38 & 19 & 19 & 0.500 \\
\hline
\end{tabular}

1) Number of males/total number of newborn mice.

a, b) Values with different superscripts differ $(\mathrm{P}<0.05)$

mice delivered 59 and 54 newborns, respectively (Table 1). The sex ratio (number of males/total number of pups) of newborns derived from the morulae with the high activity was 0.407 , while the ratio from the morulae with the low activity was 0.593 . The sex ratio of newborns derived from control morulae was 0.529 .

Two groups of blastocysts were transferred to 17 and 17 recipients, subsequently, 8 and 12 mice delivered 42 and 74 newborns, respectively (Table 1). The sex ratios of newborns with the high- and low-G6PD activity were 0.405 and 0.649 , respectively. There was a significant difference between the sex ratios of the two groups. The ratio of newborns derived from control blastocysts was 0.500 . The accuracy of the assay was $62.9 \%$ in predicting sex.

\section{Discussion}

Williams (1986) scored Day 4 mouse embryos according to BCB staining level after $30 \mathrm{~min}$ in reaction mixture. When we used the same method for assay of G6PD activity of morulae and blastocysts, 30 to $40 \%$ of embryos were not stained and activity could not be determined. Hence, we measured the time required for the embryos to reduce $\mathrm{BCB}$ to a colorless compound and represented the G6PD activity over time. Morulae and blastocysts were stained blue, while 1- to 8-cell stage embryos were not stained even after $30 \mathrm{~min}$ of staining. Moreover, the activity of blastocysts were lower than that obtained in morulae. Brinster (1966) demonstrated that G6PD activity decreased as embryos developed, and subsequently, the activity of late blastocysts was decreased to $14 \%$ of the activity of unfertilized eggs. The fact that early embryos were not stained by BCB in our experimental females in the same litter (Tsunoda et al., 1985, Miyano et al., 1989). Since G6PD activity of embryos decreases as developmental stages progress, the activity of male embryos decreases rapidly. If the activity of embryos in the same litter is assayed at a certain developmental stage, the accuracy in sex prediction might be advanced further.

\section{References}

Adler DA, West JD, Chapman VM (1977) Expression of $\alpha$-galactosidase in preimplantation mouse embryos. Nature 267: 838-839.

Brinster (1966) Glucose 6-phosphate-dehydrogenase activity in the preimplantation mouse embryo. Biochem J 101: 161-163.

Epstein CJ (1969) Mammalian oocytes: X chromosome activity. Science 163: 1078-1079.

Epstein CJ (1972) Expression of the mammalian Xchromosome before and after fertilization. Science 175: 1467-1468.

Epstein CJ, Smith S, Travis B, Tucker G (1978) Both $\mathrm{X}$-chromosomes function before visible $\mathrm{X}$ chromosome inactivation in female mouse embryos. Nature 274: 500-503. 
Kratzer PG (1983) Expression of maternally and embryonically derived hypoxanthine phosphoribosyl transferase (HPRT) activity in mouse eggs and early embryos. Genetics 104: 685-689.

Kratzer PG, Gartler SM (1978) HGPRT activity changes in preimplantation mouse embryos. Nature 274: 503-504.

Lyon MF (1961) Gene action in the X-chromosome of the Mouse (Mus musculus L.). Nature 190: 372-373.

Lyon MF (1974) Mechanisms and evolutionary origins of variable $\mathrm{X}$-chromosome activity in mammals. Proc $R$ Soc Lond B 187: 243-268.

Miyano T, Naohara K, Kato S, Kanda S (1989) Sex ratio of fast- and slow-developing mouse embryos derived from eggs fertilized in vivo and in vitro. Jpn J Anim Reprod Tech 11: 13-18 (in Japanese).

Monk M, Handyside AH (1988) Sexing of preimplantation mouse embryos by measurement of X-linked gene dosage in a single blastomere. J Reprod Fert 82: 365-368.
Quinn P, Barros C, Whittingham DG (1982) Preservation of hamster oocytes to assay the fertilizing capacity of human spermatozoa. J Reprod Fert 66: 161-168

Rieger D (1984) The measurement of metabolic activity as an approach to evaluating viability and diagnosing sex in early embryos. Theriogenology 21: 138-149.

Schultz GA (1986) Utilization of genetic information in the preimplantation mouse embryo. In: Experimental Approaches to Mammalian Embryonic Development (Rossant J, Pedersen R eds.), Cambridge Univ. Press, pp 239-265.

Tsunoda Y, Tokunaga T, Sugie T (1985) Altered sex ratio of live young after transfer of fast- and slow-developing mouse embryos. Gamete Res 12: 301-304.

Williams TJ (1986) A technique for sexing mouse embryos by a visual colorimetric assay of the X-lined enzyme, glucose 6-phosphate dehydrogenase. Theriogenology 25: 733-739.

\title{
マウス胚における X 染色体由来グルコース \\ 6 リン酸脱水素活性の性差
}

\author{
宮野 隆- 猶原 兼人 - 加藤 征史郎 - 苅田 淳 \\ 神戸大学農学部家畜繁殖学研究室 \\ 干657 神戸市灘区六甲台町 1
}

Williams (1986)の BCB 比色法によって, 着床前のマ ウス胚におけるX 染色体由来グルコース 6-リン酸脱水 素酵素 (G6PD)の活性測定を試みた。1〜8細胞期胚は BCB に不染であり，G6PD 活性を測定できなかった。 $\mathrm{BCB}$ に染色された桑実胚および胚盤胞について G6PD 活性を測定した結果, 胚盤胞の活性は桑実胚より低かっ たが，胚は二頂性の分布を示した。

桑実胚および胚盤胞を G6PD 活性の高い群と低い群
に分類した後移植し, 得られた産子の性比を調べた。 G6PD 活性の高い桑実胚および低い桑実胚に由来する産 子の性比（産子に占める雄の割合）は0.407および0.593 であり, G6PD 活性の高い群では雌が多い傾向を示した。 胚盤胞を同様に移植したところ, G6PD 活性の高い群お

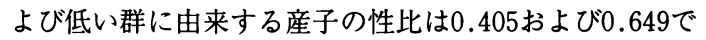
あり, G6PD 活性の高い群では雌が有意に多かった。 